\title{
THE IMPACT OF LEAN MANUFACTURING ON ENVIROMENTAL PERFORMANCE IN MOROCCAN AUTOMOTIVE INDUSTRY
}

\author{
Yassine BOUAZZA, Azza LAJJAM, Btissam DKHISSI \\ Abdelmalek Essaadi University \\ National School of Applied Sciences Tetouan
}

\begin{abstract}
:
Due to an increase in energy price and pollution plus environmental regulations, companies start to adopt green policies. In fact, companies are encouraged by governments to develop strategies to achieve more sustainable operations. Based on this literature review the contribution of Lean Manufacturing on environmental performances will be discussed, a survey of 50 different automotive companies based in Morocco, shows how they are carrying out manufacturing and environmental practices. The result of this study shows a positive impact of advanced Lean Manufacturing's tools on the environmental performance and contribute to the present literature on environmentally friendly Manufacturing. The findings and proposals of this paper can be a beginning step for Moroccan companies to completely use their capability of environmental practices and improve their manufacturing productivity performance while identifying trends in organizational development.
\end{abstract}

Key words: lean manufacturing, environmental performance, wastes

\section{INTRODUCTION}

In a context of high competition, companies aim to be more competitive to ensure their position in the market. Thanks to Lean Manufacturing companies have reduce their wastes efficiently and increase their profitability, however nowadays with new environmental concerns, companies start focusing also on sustainable development to respect the actual \& future legislation and adopt environmentally friendly policies.

Many countries have started campaigns to promote sustainable development framework insisting on use of recycled material with reduced energy consumption. Morocco is one of the emerging countries that have adopted this strategy, whose primary objective is to accelerate the gradual transition to the global green economy, especially since the COP22 has been held in Morocco.

On the one hand, Lean Manufacturing can be defined as doing more with less, based on the Toyota Production System, it focuses on eliminating activities that consumes resources without creating value, called wastes. Russel \& Taylor [1] define waste as anything other than the minimum amount of equipment, effort, materials, parts, space and time that is essential to add value to the product. From the other hand, sustainable development is defined as meeting the needs of the present without compromising the ability of future generations to meet their own needs [2]. Sustainability and environmental issues are rapidly emerging as one of the most important topics for strategic business, management, manufacturing and product development decisions.

However, there is a need to understand if Lean practices may lead to sustainable development.

In our literature review, the relationship between one or some of the Lean practices and the environmental performance will be analyzed with a focus on Moroccan automotive industry. Regarding the outcome of this studies, most of them pointed out that there is a positive relationship between Lean Manufacturing practices and the improvements in the environmental performance.

\section{LITERATURE REVIEW}

Lean Manufacturing is derived from the Toyota Production System (TPS), whose founder is Taiichi Ohno [3], in our literature review, the contribution of these tools to the environmental performance will be studied.

\section{Lean Manufacturing}

The objective of Lean Manufacturing is to improve the performance of the processes by exploiting the methods, techniques, and practices already available to the managers of industrial production. Viewed from a more practical, more concrete angle, the approach is essentially 
based on the active resolution of the recurrent problems of industrial production, whatever the field of activity. To achieve its goals manufacturing companies, use a variety of tools and methods of Lean Manufacturing. These are included in Table 1: SMED (Single Minute Exchange of Die), TPM (Total production, Maintenance), 5S, PokaYoke, and others $[4,5]$.

Table 1 Lean Tools

\begin{tabular}{l}
\hline Lean waste reduction tools and techniq \\
\hline $5 S$ \\
Value Stream Mapping (VSM) \\
Kanban \\
Kaizen \\
Poka-yoke \\
Single Minute Exchange of Dies (SMED) \\
Total Productivity Maintenance (TPM)
\end{tabular}

The concept, which allows the improvement of production processes is Lean Manufacturing. The main objective is to eliminate of all waste generated on the production and consequently reduce the transit time of the material by the process known as lead time.

Lean Manufacturing contributes on the reduction of manufacturing costs and the increase of productivity as well as the reduction of the transit time from ordering to sending the finished goods to the customer. Taiichi Ohno, in his research [4] related to Lean Manufacturing, presented in Table 2 seven types of waste: overproduction, inventory, mistakes, quality defects, waiting, over-processing, unnecessary transport and unnecessary movement. Currently, seven types of waste are enriched by yet another - untapped potential employee's $[5,6]$.

Table 2

Type of wastes on manufacturing

\begin{tabular}{ll}
\hline \multicolumn{1}{c}{ Form } & \multicolumn{1}{c}{ Description } \\
$\begin{array}{l}\text { overproduction } \\
\text { human }\end{array}$ & $\begin{array}{l}\text { the waste of making too much too soon } \\
\text { not using people's minds and getting them } \\
\text { involved }\end{array}$ \\
$\begin{array}{ll}\text { Do nources } \\
\text { transportation unnecessarily move products } \\
\text { or materials } \\
\text { inventory } & \begin{array}{l}\text { All the access products and material that } \\
\text { are not being processed }\end{array} \\
\text { motion } & \begin{array}{l}\text { All movement of equipment not done } \\
\text { in the easiest possible way }\end{array} \\
\text { corrections } & \begin{array}{l}\text { mistakes and errors that take time to fix } \\
\text { Investing more into a product than customer } \\
\text { over-processing }\end{array} \\
\text { values } & \text { idle production time where processes } \\
\text { are not optimally synchronized }\end{array}$ \\
\hline Source: [7] &
\end{tabular}

Source: [7].

\section{Environmental practices}

There are two types of Environmental practices: active (proactive or prevention) and passive (reactive or control) [8].

Active practices mean all the practices that contribute to a change on the structure of the process and affect the use of more environmentally friendly resources [9], in or- der to reduce environmental impact. The practices contribute on reducing material use and avoid waste and repairing costs, thus they constitute a value added for the company [8]. In this active approach, companies have added environmental objectives into their tactics and strategy [10].

On the other hand, passive practices involve the hole process that perceives, catches, and disposes of the emissions caused by the production process, without any structural interference [11]. those practices could be categorized as operational-level activities since they do not interfere in the organization structure. Ind addition, passive practices are in general required by external regulation from the government, the market and repeated media exposure among others [8, 12].

As explained before, passive practices resolve environmental problems to follow the external regulations without intervening in the structural organization, although active practices include environmental objectives that merge with the tactics and strategy of the company. Therefore, operational-level practices have a close relationship with a passive approach and tactical \& strategiclevel practices with an active approach. Gonzalez-Benito [13] concluded that the integration of proactive measures at different levels and functions of the company will contribute on the definition of the relationships between environmental and manufacturing practices.

It is assumed that companies will improve their environmental performance by applying these environmental practices. Carvalho et al. [14], States companies can achieve a bigger competitive advantage by making their businesses more environmentally friendly. By reducing environmental risks and impacts, environmental management practices may improve the ecological efficiency and competitiveness of a company $[15,16]$.

\section{Studies linking Lean Manufacturing and environmental performance}

According to King and Lenox [17] demonstrated Lean Manufacturing can reduce the pollution costs. Their hypotheses were confirmed by the result of their studies from 1991 to 1996 on some US companies: Lean Manufacturing have a positive impact on the environmental practices.

Chiarini [18] analyzed five European companies that produce motorcycle components and use Lean and environmental management.

The environmental impacts of the production processes of the five companies were observed and assessed before and after the implementation of Lean tools: Value Stream Mapping (VSM), 5S, cellular manufacturing, Single Minute Exchange of Die (SMED) and Total Productive Maintenance (TPM).

The examination of the quantitative results shows that: VSM is used to map the environmental impacts of production processes. $5 \mathrm{~S}$ can help to reduce the oil leakage and improve waste management. Cellular manufacturing will lead to a decrease in electricity consumption. Further- 
more, TPM can help reducing several impacts of the machines, for example: oil leakage, dusts emissions and chemical smoke into the environment

Faulkner \& Badurdeen [19] developed in the satellite dish industry a new concept called sustainable value stream mapping (Sus-VSM) methodology. VSM is one of Lean practices, this method has been used to improve production system through process mapping. However, in their research, they have added environmental aspect for example: time, energy, materials, and water. These aspects were integrated to the VSM.

Despite VSM is a visual tool that identify waste in manufacturing processes, where the main objective is to know Lean oriented production practices and develop plans to improve future performance, this study [19] has integrated economic, environmental, and social aspects of VSM with a focus on the manufacturing stage[20] Also, Pampanelli [21] proposed Lean and Green Model, this new model integrated the Lean thinking into environmental sustainability. The model used a Kaizen approach to improve energy flows in Lean Manufacturing environments.

The model was designed for, and was limited to the cell level, which is the first entrance of a manufacturing business that supports the principles of Lean thinking model. To validate this model, a major global engineering company that services the automotive and aerospace industries was taken as a case study in Brazil in 2011.
The important results of their study were that the model reduced environmental impact of the production processes and contribute on increasing the productivity as well as reducing resources use from 30 to $50 \%$ on average. In addition, there is a potential reduction of the total cost of energy flow in a cell by $5-10 \%$. [22].

From the same perspective, $\mathrm{Ng}$ [23] presented a new metric called "Carbon-Value Efficiency". This approach is the result of integration the Lean and green manufacturing. Thanks to this method that was applied in a case study of metal stamped parts products, the results showed that Carbon-Value Efficiency can be improved by $36.3 \%$, lead time has been improved by $64.7 \%$ and reduction in carbon footprint by $29.9 \%$ [22].

In addition, Thanki [24], adapted an analytical hierarchy process method to examine the impact of some Lean tools (TPM, Kaizen and 5S) and green practices (ISO 14001, 3R and DFE) on overall performance of Indian SMEs. As a conclusion of his study, the most significant practice of Lean was total productive maintenance (TPM) and the most critical criteria for Leanness were On-time delivery/quality control. Furthermore, ISO 14001 was the most important green practice and a reduction in emissions/energy consumption were the most critical criteria for Greenness [22].

In the same context, Chiarini [18]; Vinodh [25]; Cherrafi [26] stated some Lean principles/tools and sustainable benefits of each one. This is cleared as shown in Table 3.

Table 3

Environmental benefits of Lean principles

\begin{tabular}{|c|c|}
\hline Lean principle/tool & Sustainable benefits \\
\hline Just in time & $\begin{array}{l}\text { Reduction of work-in-process, Elimination of perishable products that can } \\
\text { generate waste, Optimization of space use. }\end{array}$ \\
\hline $\begin{array}{l}\text { Cellular } \\
\text { manufacturing }\end{array}$ & $\begin{array}{l}\text { Reduction of change-over and set-up time for the references } \\
\text { Energy consumption reduction, reduce defects }\end{array}$ \\
\hline $\begin{array}{ll}\text { Value } & \text { Stream } \\
\text { Mapping } & \end{array}$ & $\begin{array}{l}\text { Reduction in waste through fewer defects, } \\
\text { Optimization of resources use }\end{array}$ \\
\hline $\begin{array}{l}\text { Total preventive } \\
\text { maintenance }\end{array}$ & $\begin{array}{l}\text { Reduction of hazardous waste caused by spills and leaks of equipment's, extend } \\
\text { life of machines du maintenance }\end{array}$ \\
\hline $5 \mathrm{~S}$ & $\begin{array}{l}\text { Reduction in lighting consumption when having clean windows, } \\
\text { reduced overuse of materials. }\end{array}$ \\
\hline Six sigma & $\begin{array}{l}\text { Products have more reliably \& durability with less defects so less wastes } \\
\text { generated }\end{array}$ \\
\hline $\begin{array}{l}\text { Pre-Production } \\
\text { planning }\end{array}$ & $\begin{array}{l}\text { Reduction of waste at design stage, usage of right sized equipment's, } \\
\text { reducing the complexities of production processes and product design. }\end{array}$ \\
\hline Kaizen & Eliminates non-value-added activities and hidden wastes \\
\hline Visual controls & $\begin{array}{l}\text { Identification and elimination of unnecessary departments, } \\
\text { so less material usage and wastes. }\end{array}$ \\
\hline $\begin{array}{ll}\text { Lean supplier } \\
\text { networks }\end{array}$ & $\begin{array}{l}\text { Existing suppliers using lean manufacturing can contribute to an } \\
\text { environmental benefits. }\end{array}$ \\
\hline PoKa YoKe & Less scrap and less waste due to reduction of defects or detection in a prior phase \\
\hline
\end{tabular}

Source: $[17,22]$. 
The Environmental Protection Agency EPA [27] discussed a correlation between the seven Lean wastes and the environmental impacts they can create as shown in Table 4.

Table 4

Environmental impacts linked with type of manufacturing waste

\begin{tabular}{ll}
\hline Waste type & \multicolumn{1}{c}{ Environmental impact } \\
\hline & Raw materials consumed in making defective \\
& products. \\
& Defective components require recycling or dis- \\
posal. & More space required for rework and repair, in- \\
creasing energy use for heating, cooling, and \\
lighting.
\end{tabular}

Waiting

Potential material spoilage or component damage causing waste.

Wasted energy from heating, cooling, and lighting during production downtime.

Overpro- unneeded Products.

More raw materials consumed in making the

duction Extra products may spoil or become obsolete requiring disposal.

More energy use for product transportation. Emissions from transportation.

Movement More space required for work-in-process (WIP)

and trans- movement, increasing lighting, heating, and

portation cooling demand and energy consumption.

More packaging required to protect compo-

nents during movement.

More packaging to store WIP.

Waste from damage to stored WIP.

Inventory More materials needed to replace damaged WIP.

More energy used to heat, cool, and light inventory space.

Complexity More parts and raw materials consumed per and over unit of production.

processing Unnecessary processing increases wastes, energy use, and emissions

Source: EPA [27, 28].

\section{METHODOLOGIE OF RESEARCH}

Quantitative data method collection has been used for this study, the main objective of this research is to give a depth understanding of organizations in Morocco related to Lean Manufacturing and environmental performance [16]. This study includes 50 from automotive sector, more than 100 manufacturers were contacted. The choice of automotive industry was predetermined to confirm that companies have already used one or some Lean tools.

The companies surveyed are in the region of Tangier and Kenitra in the north of Morocco where almost all automotive company are located.
Managers that inquired into manufacturing and environmental practices inside their company were selected for data collection using open- ended surveys.

Initially, all the respondents were interviewed to ensure the same understanding and comprehension of the study physical business characteristics such as company age Fig. 1 (a) and size (number of employees) Fig. 1 (b) were also indicated [16].

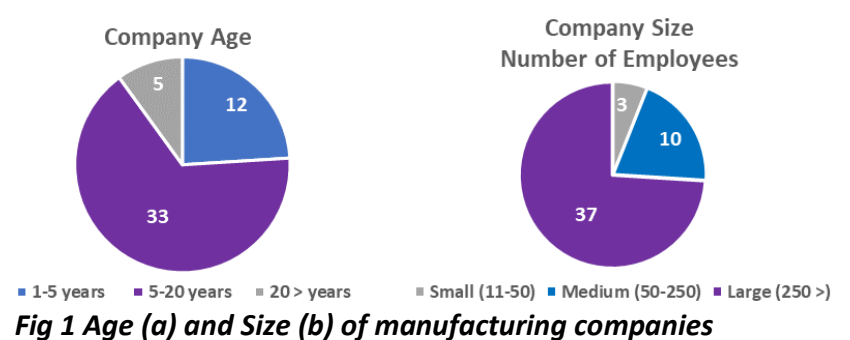

Due to the type of the study, a non-probabilistic purposive sample was used.

Hence, this paper present empirical evidence about how manufacturing companies in the automotive sector in Morocco carry out production management and environmental practices rather than attempt to draw statistical generalization from the results [16].

It should be specified that this study only focuses on the type of practices used and does not examine their implementation process. Fig. 1 outlines some interesting data from the sample.

From this data we can notice that $90 \%$ of automotive companies are under 20 years and only $10 \%$ are above, in fact the majority of companies have started their implementation when Renault automotive constructor has settled in 2008 and started their production in 2012 and after that with the establishment of second constructor PeugeotCitroen in 2018. For the size of companies, $74 \%$ have more than 250 of workers, this can be explained due to the type of industry which required a lot of workforce.

\section{RESULTS OF RESEARCH}

This part of the study shows the empirical results reviews the environmental and manufacturing practices found in the companies that were assessed.

\section{Manufacturing practices}

All the companies use one or more Lean Manufacturing tool, this is a singularity related to the automotive sector. As conclusion from the Fig. 2, the most used tools are 5S, Kaizen and Poka Yoke, these practices are easy to implement in companies and do not require a big investment, the results can be seen almost immediately. 


\section{Lean Manufacturing Tools}

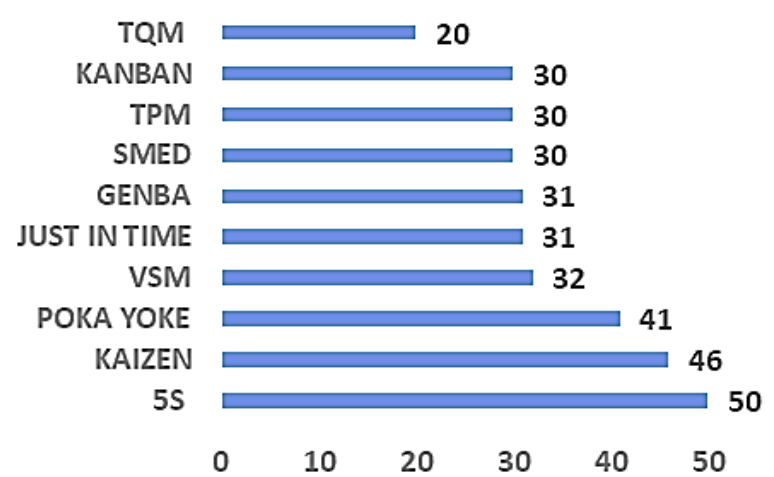

Fig 2 Count of Lean Manufacturing tools in companies

The least used tool is TQM, this result is due to common mix with the ISO 9001, that in general all automotive industries have this certification in addition to ISO IATF, it's an interesting starting point for total quality, while it does not fully cover the principles of TQM, it nevertheless facilitates the adoption of new compatible points of view.

Advanced manufacturing practices can be illustrated as the activities settled or the processes approved by a company to achieve its objectives by implementing wellknown manufacturing tools. These manufacturing practices include manufacturing resource planning, flexible manufacturing systems, group technology, total quality management (TQM), just-in-time delivery (JIT), Lean production (LP), concurrent engineering, continuous improvement, etc. [16]. From our data, we identified which companies apply five or more manufacturing practices and classified them by company size in Fig. 3.

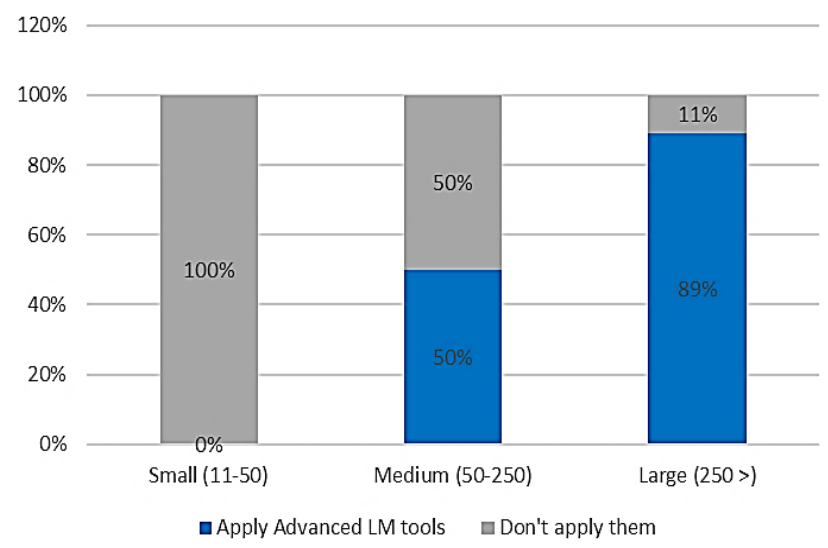

Fig. 3 Manufacturing companies

From company size perspective, large companies (89) are more committed applying advanced manufacturing practices than the smaller companies did. The logic here is that large companies need a common framework to spread a shared corporate culture for continuous improvement practices.
Note that there is a directly proportional relationship between company size and the use of advanced manufacturing practices [16].

\section{Relation between Lean and environmental wastes}

Fig. 4 shows the types of wastes, the most three important wastes that were raised are defects, unnecessary movement and waiting, based on the EPA [27], defectives parts generate a consumption of raw materials and require recycling or disposal, if they will be repaired they will require more energy and space for rework.

Waiting can cause potential material spoilage and damage generating wastes and require recycling or use of energy during production downtime, unnecessary movement will require more energy use.

The prediction based on this is that the consumption of raw materials, the use of energy, waste generation and recycling will be the most important environmental wastes on these companies.

To confirm our hypothesis, the Fig. 5 shows the environmental wastes, the excessive use of energy and waste management are on the top, a correlation between the type of Lean wastes and the environmental ones can be deduced.

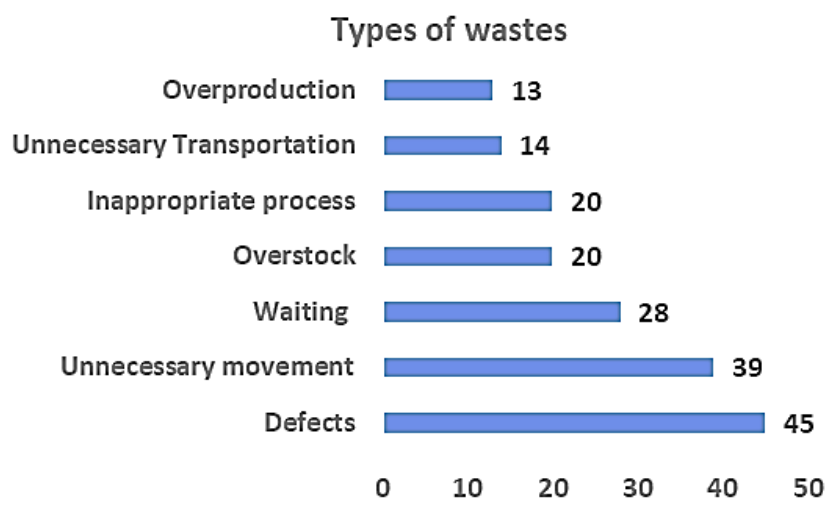

Fig. 4 Count type of wastes in companies

\section{Enviromental Wastes}

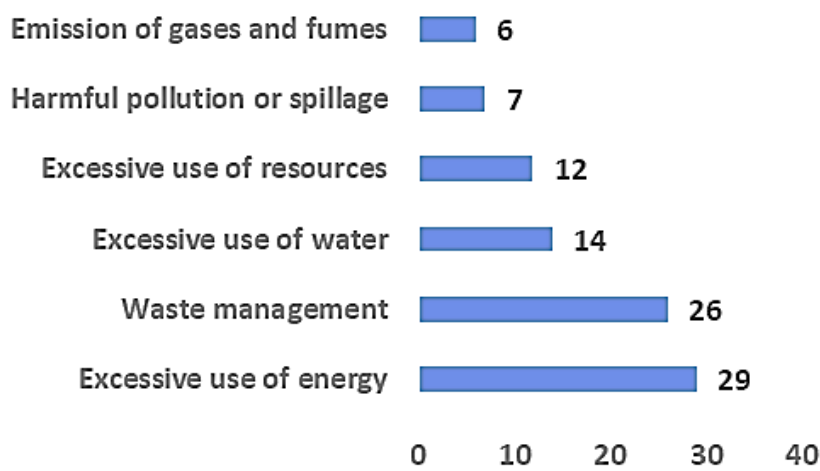

Fig. 5 Count of environmental wastes of companies 
Relationship between manufacturing and environmental management practices

King and Lenox [17], admit the existence of potential complementarities between manufacturing and environmental practices, and thus companies should consider applying these practices in parallel.

According to Yang [29] environmental management is partially an extension of advanced manufacturing practices, continuous improvement, and supplier management because a significant segment of environmental programs is based on the pillars of manufacturing practices [16].

In this situation, it is accepted that companies with advanced manufacturing practices have established a durable active participation in environmental management within their organizations, and vice-versa [13].

In this case study, Fig. 6 shows that $80 \%$ of companies with advanced manufacturing practices have developed tactical and strategic environmental management practices (i.e., active environmental approach). In addition, $100 \%$ of the same companies (i.e., companies with advanced manufacturing practices) have operational environmental practices. Note that a company could apply operationallevel practices, tactical and strategic-level practices at the same time [16].

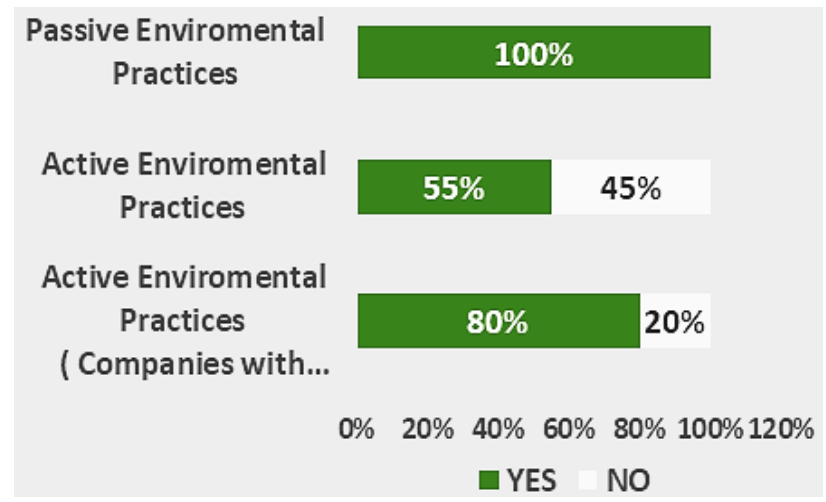

Fig. 6 Environmental practices with Lean Manufacturing practices in companies

These results show that companies with advanced manufacturing practices present a more proactive approach in environmental development regarding other companies. That is, $80 \%$ of these manufactures have developed tactical and strategic practices inside their companies, while a large majority apply operational-level practices [16]. The Fig. 7, shows number of responders related to the impact of Lean Manufacturing on environmental performance.

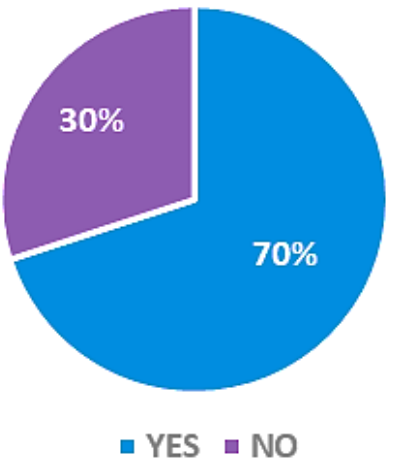

Fig. 7 Relation Between Lean Manufacturing and environmental performance

The majority $70 \%$ acknowledge the positive contribution of Lean Manufacturing towards environmental performance. The respondents' opinion leads to a conclusive relationship between the two concepts. On the one hand, the interviewers admit that the evolution of both concepts is linked and correlated. Although they may share some disparity in focuses, because one being on production/service optimization in a cost-effective manner and the other being on environmental improvement, with a much deep approach than just the economic benefit.

On the other hand, they think there is a relation between the practical output they generate both concepts. Respondents believe in the existence of synergies between Lean Manufacturing and environmental performance but there is mixed while it comes to link the seven wastes of Lean Manufacturing and environmental performance [26].

The Fig 8 shows the relation between the responses of interviews and the existence of active environmental practices in their company.

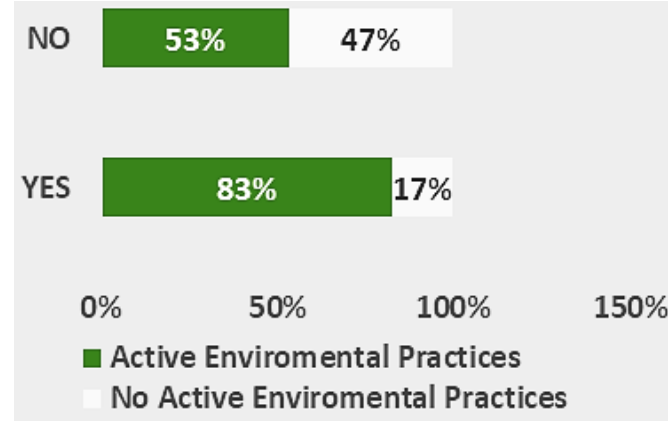

Fig. 8 Relation between Lean Manufacturing and active/passive environmental practices 
The organizations with actives environmental activities are more likely to believe $(83 \%)$ in the relation between the Lean Manufacturing and environmental performance. However the rest (53\%)of the interviewers does have actives environmental performances still believe that there is no relationship, this can be explained as these findings are also consistent with the study by D'Amico [30], which argues that there is a low level of disclosure of environmental information by company employees because of incorrect environmental management inside companies [16].

The implementation of actives practices such as environmental department, helps companies to better work with collaboration of engineering department and continuous improvement department to relate the application of Lean Manufacturing tools on the environmental performance.

\section{DISCUSSION}

The automotive industry is playing an important role in the economy of Morocco and providing employment opportunities and better conditions of work. The study explains whether Lean Manufacturing influences environmental performances in Moroccan automotive industry or not. The findings reveal significant positive effects of Lean Manufacturing on sustainability benefits. These results give the evidence that Lean Manufacturing can be explored for achieving the sustainability [31].

The result of the survey also agrees with most of the literature, which indicated a positive relationship between Lean Manufacturing and environmental performance [17, 18].

The positive relationship of Lean Manufacturing and environmental performances is already established from the previous works [16, 23, 26] which this study further confirms in Moroccan automotive companies. The findings acquire greater significance, as Morocco is one of the developing countries in which automotive companies are playing a crucial role, and where government authorities are promoting sustainable development.

The findings in this paper are crucial and relevant than the earlier works conducted in this field precisely because Lean Manufacturing has a positive link towards the social benefits [31].

Based on the previous studies and both Tables ( 3 and 4) presented above, the conclusion regarding the impact of Lean Manufacturing on environmental performance [32] as shown in Table 5.
Table 5

Effect of 7 wastes Lean on environmental Performance

\begin{tabular}{|c|c|c|}
\hline $\begin{array}{c}\text { Lean } \\
\text { waste }\end{array}$ & Impact & Benefit \\
\hline 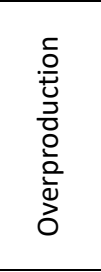 & $\begin{array}{l}\text { Perform a task that does } \\
\text { not meet any demand } \\
\text { or customer require- } \\
\text { ment. } \\
\text { Generate extra waste } \\
\text { and emission. }\end{array}$ & $\begin{array}{l}\text { Without overproducing } \\
\text { the consumption of en- } \\
\text { ergy and the use of raw } \\
\text { material will be reduced } \\
\text { as well as the generation } \\
\text { of overstocks that can } \\
\text { became wastes }\end{array}$ \\
\hline
\end{tabular}

\begin{tabular}{|c|c|c|}
\hline 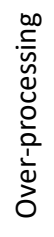 & $\begin{array}{l}\text { Over-processing leads } \\
\text { to use extra parts and } \\
\text { raw material to produce } \\
\text { the same part, generat- } \\
\text { ing more waste and en- } \\
\text { ergy consumption }\end{array}$ & $\begin{array}{l}\text { Improving processing to } \\
\text { use the necessary mate- } \\
\text { rials for production con- } \\
\text { tribute on reduction of } \\
\text { wastes and emissions }\end{array}$ \\
\hline 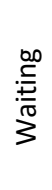 & $\begin{array}{l}\text { Waiting contribute to } \\
\text { over-use of energy such } \\
\text { ass electricity and heat- } \\
\text { ing can cause damage } \\
\text { for some special part. }\end{array}$ & $\begin{array}{l}\text { Reduce lead time which } \\
\text { will contribute to a bet- } \\
\text { ter energy use }\end{array}$ \\
\hline
\end{tabular}

\begin{tabular}{|c|c|}
\hline 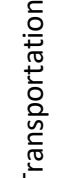 & $\begin{array}{l}\text { transportation leads to } \\
\text { extra consumption o } \\
\text { energies and therefore } \\
\text { extra emissions }\end{array}$ \\
\hline
\end{tabular}

Optimizing transportation leads to reduction cost and less energy use

by having less product inventory sitting around, organizations can use A bad inventory can their plant space more generate outdated and efficiently (saving heatnon-conforming parts ing and cooling dethat will become wastes mands) whilst also conand should be thrown in suming less packaging addition of having big in- and raw materials, ventory demand the use Lower levels of invenof additional energy. tory also reduce the risk of waste due to obsolescence and undiscovered defects

minimizing product defects means organizations are using fewer raw materials to manufacture products, which equals less energy consumption

reducing any effort of lifting things unnecessarily or the needing to walk an excessive distance back and forth to find tools or complete a task means organization will use less energy duce a product resulting in increased energy requirements cooling, and lightin demands, it can also in-

Defects parts generates use of extra energy or material for repair or new production.

.




\section{CONCLUSION}

After examining the relationship between Lean Manufacturing and its impact on environmental performance some important conclusions can be summarized.

Not only most of these studies confirms the relationship between one or some of the Lean practices and the environmental performance. In addition, these studies were applied to different business environments. Among these environments are USA, Europe, India, Brazil and Spain.

Even though, Lean tools are nowadays considered standard tools. However, the study shows that these tools contribute to reduce costs as well as to help companies to be environmentally friendly.

With the ever-increasing energy demand, energy costs will evolve in the future and regulations will be stricter. Only factories committed to green will overcome these changes. It is therefore becoming increasingly important for the companies to assess their energy consumption through regular audits and to adapt sustainability.

When these tools and techniques are used correctly, they will have a positive and widespread impact on the profits of companies after their implementation.

The survey contribution done in Moroccan automotive industry represent a beginning stage for new studies that can be done in Morocco in other industries, similar research are necessary to expand the current manufacturing theory into a more integrated approach on resource productive manufacturing.

Thanks to data collection from the semi-structured interviews realized with a group of companies, this study has established and investigate the manufacturing and environmental practices within automotive factories In this study, different aspects (i.e. size, manufacturing practices and environ-mental practice level) were used to classify and determine the actual status of environmental management in the manufacturing field in a region which can be considered representative of the most advanced regions in Morocco.

This study is a starting point for future research's in the same region and contributes to the actual discussion in the literature on environmentally friendly manufacturing by demonstrating that companies could efficiently engage in proactive participation in environmental management inside their organizations if they use advanced manufacturing practices .

Conclusively, although this study brings some evidence regarding environmental management withing manufacturing companies, future studies should consider other methodologies that contribute on the adoption of proactive environmental activities. Researchers and academics should continue investigating the interrelationships between the practices described in this paper.

\section{REFERENCES}

[1] R.S. Russell, B.W. Taylor "Operations management creating value along the supply chain". Allyn \& Bacon, 3rd edition, 1999.
[2] Brundtland Commission 1983 [online] Available at: https://en.wikipedia.org/wiki/Brundtland_Commission [Accessed 30 Apr. 2019].

[3] J. Liker, D. Meier. "The Toyota Way Fieldbook: A Practical Guide for Implementing Toyota's 4Ps". McGraw-Hill Education; 1st edition, October 19, 2005.

[4] T. Ohno. "Toyota Production System: Beyond Large-Scale Production" Productivity Press, 1988.

[5] TUGAS SOFTSKIL [online] Available at: http://dodiroysyahputra.blogspot.com/ [Accessed 30Apr. 2020].

[6] J.P. Womack, D.T. Jones. "Lean Thinking: Banish Waste and Create Wealth in Your Corporation". Journal of the Operational Research Society, Vol. 48, pp. 10-57, 1997.

[7] K. Blaz, "7 Wastes of lean - How to eliminate all non-valueadded activities?" Spica International 2020. [online] Spica.com. Available at: <https://www.spica.com/blog/7wastes-of-lean $>$ [Accessed 27 October 2020].

[8] S. Rothenberg, F. Pil, J. Maxwell. "Lean, green, and the quest for superior environmental performance". Production Operational Management, Vol. 10, pp. 228-243, 2001.

[9] A. Galeazzo, A.Furlan, A.Vinelli. "Lean and green in action: inter dependencies and performance of pollution prevention projects". Journal of Cleaner Production, Vol. 85 , pp. 191-200, 2014.

[10] M. Ormazabal. "EMM Model, Environmental Management Maturity Model for Industrial Companies" . Doctoral dissertation, Universidad de Navarra, 2013.

[11] A. Galeazzo, A. Furlan, A. Vinelli. "Understanding environmental-operations integration: the case of pollution prevention projects". International Journal of Production Economics, Vol. 153, pp. 149-160, 2014.

[12] X. Xie, Z. Zang, G. Qi. "Assessing the environmental management efficiency of manufacturing sectors: evidence from emerging economies". Journal of Cleaner Production, Vol. 112, pp. 1422-1431, 2016.

[13] J. Gonzalez-Benito, O. Gonzalez-Benito. “Operations management practices linked to the adoption of ISO 14001: an empirical analysis of Spanish manufacturing". International Journal of Production Economics, Vol. 113, pp. 6073, 2008.

[14] H. Carvalho, K. Govindan, S.G Azevedo, V. Cruz-Machado. "Modelling Green and Lean supply chains: an eco-efficiency perspective resources". Resources, Conservation and Recycling, Vol. 120, pp. 75-87, 2017.

[15] Q. Zhu, J. Sarkis, K.H. Lai. "Initiatives and outcomes of green supply chain management implementation by Chinese manufacturers". Journal of Environnemental Management, Vol. 85, pp. 179-189, 2007.

[16] V. Muñoz, J. Andrés, Santos, E. Viles, M. Ormazabal. “Manufacturing and environmental practices in the Spanish context". Journal of Cleaner Production. Volume 178, pp 268275, 2018

[17] A.A; King, M.J Lenox, M.J. "Lean and Green? An Empirical Examination of the Relationship between Lean Production and Environmental Performance". Production and Operations Management, Vol. 10, pp. 244-256, 2001.

[18] A. Chiarini. "Sustainable manufacturing-greening processes using specific Lean Production tools: An empirical observation from European motorcycle component manufacturers". Journal of Cleaner Production, Vol. 85, pp. 226-233, 2014.

[19] W. Faulkner and F. Badurdeen. "Sustainable Value Stream Mapping (Sus-VSM): Methodology to visualize and assess manufacturing sustainability performance". Journal of Cleaner Production, Vol. 85, pp. 8-18, 2014. 
[20] W. Megayanti, M. Anityasari, U. Ciptomulyono "SUSTAINABLE SUPPY CHAIN VALUE STREAM MAPPING (SSC-VSM) The Application in Two Bottle Drinking Water Companies" Proceedings of the International Conference on Industrial Engineering and Operations Management Bandung, Indonesia, March 6-8, 2018, IEOM Society International .

[21] A. Pampanelli, P. Found, and A. Bernardes. "A Lean \& Green Model for a production cell". Journal of Cleaner Production, Vol. 85, pp. 19-30, 2014

[22] M.A. Abu-Bakr, M.G. Abdel-Kader, A.F. Elbayoumi "Measuring the Impact of Lean Manufacturing Practices on Sustainability Performance: A Proposed Model "Cairo University International Conference on Business Sciences (CUCBS 2017): Roadmaps for Sustainable Businesses: Cairo, Egypt.

[23] R. Ng, J. Low and B. Song. "Integrating and implementing Lean and Green practices based on proposition of CarbonValue Efficiency metric". Journal of Cleaner Production, Vol. 95, pp. 242-255, 2015.

[24] S. Thanki, K. Govindan, K. and J. Thakkar, "An investigation on Lean-Green implementation practices in Indian SMEs using analytical hierarchy process (AHP) approach". Journal of Cleaner Production, Vol. 135, pp. 284-298, 2016.

[25] S. Vinodh, K. Arvind, M. Somanaathan. "Tools and techniques for enabling sustainability through Lean initiatives". Clean Technologies and Environmental Policy. Vol. 13, pp. 469-479, 2010.

[26] S.P. Nadeem, J.A. Garza-Reyes, S.C. Leung, A. Cherrafi, T. Anosike, M.K. Lim. "Lean Manufacturing and environmental performance - exploring the impact and relationship", IFIP International Conference on Advances in Production Management Systems (APMS 2017): Advances in Production Management Systems. The Path to Intelligent, Collaborative and Sustainable Manufacturing, Hamburg, Germany, September 3-7, pp. 331-340, 2017.

\footnotetext{
Yassine Bouazza (Corresponding Autor's)

Abdelmalek Essaadi University

National School of Applied Sciences Tetouan

Avenue of Palestine Mhannech I

Tetouan, 93002, Morocco

e-mail: yassinbouazza@gmail.com
}

\section{Azza Lajjam}

Abdelmalek Essaadi University

National School of Applied Sciences Tetouan

Avenue of Palestine Mhannech I

Tetouan, 93002, Morocco

e-mail: azza.lajjam@gmail.com

\section{Btissam Dkhissi}

Abdelmalek Essaadi University

National School of Applied Sciences Tetouan

Avenue of Palestine Mhannech I

Tetouan, 93002, Morocco

e-mail: dkhissi_btissam@yahoo.fr
[27] US EPA. (n.d.). US EPA. [online] Available at: https://www.epa.gov/ [Accessed 10 Apr. 2019].

[28] S. Lamichaney, K.R. Baranwal, K.M. Swapan, G.Majumdar. "Quality of Environment and Clean Manufacturing", Elsevier BV, 2020.

[29] C.-L. Yang, S.-P. Lin, Y. Chan, C. Sheu "Mediated effect of environmental management on manufacturing competitiveness: an empirical study", International Journal of Production Economy, Vol. 123, pp. 210-220, 2010.

[30] E. D'Amico, D. Coluccia, S. Fontana, S. Solimene. "Factors influencing corporate environmental disclosure". Business strategy and the Environment, Vol. 25, pp. 178-192, 2014.

[31] M.P. Sajan, P.R. Shalij, A. Ramesh, P.A. Biju "Lean manufacturing practices in Indian manufacturing SMEs and their effect on sustainability performance", Journal of Manufacturing Technology Management, Vol. 28 No. 6, pp. 772793, 2017.

[32] C.R.A. Hallam, C. Contreras. "The Interrelation of Lean and Green Manufacturing Practices: A Case of Push or Pull in Implementation ", 2016 Proceedings of PICMET '16: Technology Management for Social Innovation the University of Texas, San Antonio, USA. 